\title{
New alpine and subalpine species in Craspedia sens. strict. (Asteraceae: Gnaphalieae)
}

\author{
J. Everett and J. Thompson
}

\begin{abstract}
Everett, J. and Thompson, J. (National Herbarium of New South Wales, Royal Botanic Gardens, Sydney, NSW, Australia 2000) 1992. New alpine and subalpine species in Craspedia sens. strict. (Asteraceae: Gnaphalieae). Telopea 5(1): 45-51. The new species Craspedia coolaminica, C. maxgrayi, C. alba, C. crocata, C. jamesii, C. aurantia, C. costiniana and C. lamicola are described, all of them occuring only in alpine or subalpine areas. Notes on the flowering periods, habitat and general distribution are included.
\end{abstract}

\section{Introduction}

Prior to the publication of an account of Craspedia Forst. f. (Asteraceae: Gnaphalieae) in volume 3 of the Flora of New South Wales it is necessary to describe the following eight new species. These species have been known by a confusing range of alphabetic codes used in various publications. Thompson (1981) based the alphabetic codes for six of the nine undescribed species in Kosciusko National Park on Costin et al. (1979) adding three further species to their alphabetic series. Jacobs \& Pickard (1981) referred to sixteen undescribed species of Craspedia sens. lat., as used at the time in the $\mathrm{Na}$ tional Herbarium of New South Wales, with a different alphabetic series that does not correspond to the other two publications. Herbarium specimens carry annotations from yet another incongruent alphabetic series.

This paper deals with alpine and subalpine species of Craspedia sens. strict. Craspedia sens. strict covers those plants with pedunculate capitula within the compound head. Other papers dealing with non-alpine Craspedia species, and those species with sessile capitula under the generic name Pycnosorus, appear in this volume.

\section{C. coolaminica Everett $\mathcal{E}$ Thompson, sp. nov.}

Species foliis argenteis, basibus foliorum longe attenuatis, a speciebus nobis notis distincta.

TYPE: New South WALES: Southern Tablelands: Happy Jacks, Snowy Mountains, near Happy Jacks Road, above sheepyard, M.E. Phillips 20419, 27 Jan 1964 (holo NSW; iso $\mathrm{CBG})$.

Silver-grey herb with a single flowering scape 8-65 cm high; roots thick, tomentose. Leaves mainly basal, linear to narrow-spathulate, narrow-attenuate at the base, acute to broad-acuminate, 5-20 cm long, 5-20 mm wide; upper surface silvery with dense, long, fine, appressed hairs, lower surface grey-green with sparse, fine, appressed hairs; margins woolly with long fine hairs. Inflorescence a single globose to hemispherical terminal compound head. Scape cream to red, glandular or with multiseptate hairs at the base and woolly upwards. Compound head $1-2.5 \mathrm{~cm}$ diam., with c. 25-100 partial heads. Partial heads with 6-8 florets; main bract of the partial involucre broadly triangular to ovate, with an ovate or triangular herbaceous stereome, 
finely woolly at the base and with a broad, dark brown membranous margin or lobes. Corolla yellow; achenes $0.5-2 \mathrm{~mm}$ long with silky hairs; pappus of $13-18$ plumose bristles $2-4.5 \mathrm{~mm}$ long.

DeRIVATION: Refers to Coolamine Plain in Kosciusko National Park, which is one of the habitats of this species.

FLOWERING PERIOD: Summer.

HABITAT: Subalpine, among grasses on creek flats and in eucalypt woodland.

Distribution: Subalpine areas of Victoria, Tasmania and New South Wales.

Can be distinguished from other subalpine Craspedias by the long-attenuate, silverygrey leaves and small compound heads. This species was referred to as sp. $K$ in Jacobs \& Pickard (1981), and as sp. G in Thompson (1981).

Selected SPecimens: New South Wales: Southern Tablelands: $84 \mathrm{~km}$ SE of Tumut, Jacobs 4638, 15 Dec 1985 (NSW); $5 \mathrm{~km} \mathrm{~W}$ of Tolbar Rd on Happy Jacks Rd, Everett 1047 \& Stanberg, 3 Feb 1989 (NSW). Victoria: $1.5 \mathrm{~km}$ NNE of Mt Cope, van Rees 298, 1 Jan 1982 (NSW ex MEL); Gow Plain, Dargo High Plains, Walsh 598, 5 Jan 1982 (NSW ex MEL); Mt Higginbotham, Forbes 749, 12 Jan 1982 (NSW ex MEL).

\section{C. maxgrayi Everett $\&$ Thompson, sp. nov.}

Species grandis tomento argenteo a speciebus nobis notis distincta.

TYPE: New SOUTH WALEs: Southern Tablelands: Mt Kosciusko, M. Gray 4756, 25 Feb 1960 (holo NSW; iso CANB).

Silvery-white woolly herb with a single flowering scape $20-50 \mathrm{~cm}$ high; roots thick, tomentose. Leaves mainly basal, oblanceolate to narrow-spathulate, slightly tapered at the base, 5-15 cm long, 5-15 $\mathrm{mm}$ wide; both surfaces and margins silvery-white and densely white-woolly. Inflorescence a single globose terminal compound head. Scape red-brown, densely woolly with long fine hairs. Compound head $2.5-4.5 \mathrm{~cm}$ wide, with c. 70-120 partial heads. Partial heads with 9-11 florets; main bract of the partial involucre broadly triangular to ovate, with an ovate or triangular, herbaceous minutely glandular stereome, finely woolly at the base and with a dark brown membranous margin. Corolla yellow; achenes 1-1.5 mm long with silky hairs; pappus of $12-15$ plumose bristles $2.5-5 \mathrm{~mm}$ long.

DeRIVATION: Named in honour of Max Gray, a colleague from CANB who has worked extensively on the alpine and subalpine flora of the Southern Tablelands, and particularly in recognition of his work on Craspedia.

FLOWERING PERIOD: Summer.

HABITAT: Usually alpine, occasionally subalpine, in grassland.

Distribution: New South Wales and Victoria.

This is the largest silvery-white Craspedia in the alpine or subalpine areas, both in height and in size of the flowering heads. This species was referred to as sp. $\mathrm{J}$ in Jacobs \& Pickard (1981), and as sp. C in Costin et al. (1979) and Thompson (1981).

Selected specimens: New South Wales: Southern Tablelands: Snowy R. above Guthega Dam, Thompson 1741, 26 Jan 1973 (NSW, CBG, MEL); Etheridge Range, Totterdell 279a, 4 Feb 1972 (CANB, NSW); slopes of Mt Twynam, Hind 5540, 3 Mar 1988 (NSW, CBG); Mt Tate, Thompson 2941, 10 Feb 1978 (NSW). VICTORIA: near Mt Loch carpark, Hotham Heights, Everett 836, 8 Feb 1985 (NSW). 


\section{C. alba Everett $\mathcal{E}$ Thompson, sp. nov.}

Species pusilla flosculis albis, tomento albo, a speciebus nobis notis distincta.

TYPE: Victoria: Bogong High Plains, Pretty Valley, Cope Creek, S.J. Forbes 1189, 4 Dec 1982 (holo MEL; iso NSW, CANB).

Small herb with a single flowering scape 9-15 cm high; roots thick, tomentose. Leaves mostly basal, oblong to narrow-oblanceolate, $1.5-5 \mathrm{~cm}$ long, $2-5 \mathrm{~mm}$ wide, often folded; lower surface with a silvery covering of long fine appressed hairs, upper surface similar, rarely glabrescent in upper leaves; margins entire or undulate, glabrescent or silky-hairy; upper leaves decurrent. Inflorescence a single hemispherical terminal compound head. Scape red with dense silvery hairs. Compound head 1-1.5 cm diam., with c. 30-60 partial heads. Partial heads with 4-5 florets; main bract of the partial involucre broadly ovate-cordate, with an ovate to triangular glandular and herbaceous stereome, finely woolly at the base, and broad, dark brown membranous margins. Corolla white; achenes 1-1.5 mm long, with silky hairs; pappus of 12-18 colourless plumose bristles 2-3 $\mathrm{mm}$ long.

DeRIVATION: Refers to the white colour of the corolla and leaves.

FLOWERING PERIOD: Summer.

НАВITAT: In moist depressions and alpine bogs, often growing with leaves partially submerged.

Distribution: Rare. In very few areas of alpine New South Wales and Victoria, presumably because of the restricted distribution of appropriate habitats.

This species is distinguished from other silvery-leaved Craspedias by its white flowers and small size. The only other mainland white-flowered species, C. leucantha, has long, green leaves. This species was referred to as sp. H in Jacobs \& Pickard (1981), and as sp. A in Costin et al. (1979) and Thompson (1981).

SELECTED SPECIMENS: The localities given are approximate; more accurate locality details are on record at NSW and can be made available where appropriate.

New SoutH WALEs: Southern Tablelands: Cootapatamba Creek, Thompson 3054, 4 Apr 1979 (NSW, CANB); 1 km NW of Charlottes Pass, Everett 1041 \& Stanberg, 2 Feb 1989; Snowy River, below junction with Merritts Creek, Thompson 3079, 6 Apr 1979 (NSW, CBG). VICTORIA: NW of Mt Cope, van Rees 290, 31 Dec 1981 (NSW, CANB, MEL n.v.).

\section{C. crocata Everett \& Thompson, sp. nov.}

Species capitulis compositis croceis, basibus foliorum longe attenuatis, a speciebus nobis notis distincta.

Type: New South Wales: Southern Tablelands: Pipers Creek near junction with Daners Creek, J. Everett 1395, 2 Feb 1989 (holo NSW 213348; iso MEL, CBG).

Herb with a single flowering scape $12-52 \mathrm{~cm}$ high; roots thick, tomentose. Leaves mainly basal; upper surface green with scattered glandular hairs with translucent globules or glabrous, lower surface with similar glandular hairs or with multi-septate hairs; margins with finely woolly or multi-septate hairs, tips glabrous or with sparse, loose woolly hairs. Basal leaves linear-spathulate to spathulate, extremely long-attenuate at the base, 5-25 cm long, 2-12 mm wide. Upper leaves stem-clasping and acuminate, $0.5-15 \mathrm{~cm}$ long, 1-10 mm wide. Inflorescence a single spherical terminal compound head. Scape straw-coloured to crimson with multi-septate and/or long fine hairs. Compound head 1-2 cm diam., with c. 30-60 partial heads. Partial heads 
with 5-10 florets; main bract of the partial involucre triangular to ovate or cordate, with an ovate to triangular herbaceous stereome, finely woolly at the base, occasionally with hairs on the margins, and with dark brown membranous margins or lobes. Corolla deep reddishorange; achenes $0.5-1.5 \mathrm{~mm}$ long, with silky hairs; pappus of 14-18 plumose bristles $2-5 \mathrm{~mm}$ long.

DERIVATION: From the Latin croceus referring to the red-orange colour of the flowering heads.

FLOWERING PERIOD: Summer.

HABITAT: Uncommon in lower subalpine grasslands, usually in moister areas associated with stream catchments.

Distribution: Subalpine New South Wales and Victoria.

Can be distinguished by the extremely attenuate leaf bases usually red-tinged and the deep reddish orange colour of the corolla. This species was referred to as sp. A in Jacobs \& Pickard (1981) and sp. I in Thompson (1981).

Selected specimens: New South Wales: Southern Tablelands: Bimberi Range, Murrays Gap, Canning 4184, 2 Feb 1977 (NSW, CANB n.v.); base of Mt Piper, Thompson 2423, 23 Jan 1976 (NSW, CANB n.v.); 1 km N of Horse Camp Hut, Everett 895 \& Norris, 14 Feb 1985 (NSW); near Diggers Creek Reservoir, Thompson 1457, 21 Jan 1972 (NSW, CANB).

\section{C. jamesii Everett $\mathcal{E}$ Thompson, sp. nov.}

Species capitulis compositis hemisphaericis citrinus, foliis spathulatis viridisque, a speciebus nobis notis distincta.

Type: New South Wales: Southern Tablelands: between Pryors Hut and Mt Ginini, Brindabella Range, A.C.T., 35 33'S $148^{\circ} 46^{\prime} \mathrm{E}, 1600 \mathrm{~m}$, R. Coveny 11542 \& P. Hind, 19 Jan 1983 (holo NSW; iso CBG).

Bright green herb with a single flowering scape $25-80 \mathrm{~cm}$ high; roots thick, tomentose. Leaves bright green, mainly basal, spathulate, usually long-attenuate at the base, acute to broad-acuminate, $3.5-20 \mathrm{~cm}$ long, 5-30 mm wide; surfaces and margins evenly covered with multi-septate or occasionally glandular hairs or glabrous, the tips glabrous. Upper leaves lanceolate, stem-clasping, $0.5-17 \mathrm{~cm}$ long, 2-20 mm wide. Inflorescence a more or less flattened hemispherical terminal compound head. Scape cream to crimson with multi-septate or glandular hairs. Compound head $1.5-3.5 \mathrm{~cm}$ in diameter with c. 25-125 partial heads. Partial heads with 5-12 florets; main bract of the partial involucre broadly triangular to ovate, often with three distinct lobes, with a generally ovate herbaceous stereome with silky hairs at the base and occasionally hairy in the centre or on the margins, the lobes and margins membranous. Corolla golden-yellow; achenes $0.5-2.0 \mathrm{~mm}$ long, with silky hairs; pappus of 14-24 plumose bristles $1.5-5.5 \mathrm{~mm}$ long.

Derivation: Named after Joy Everett's son James Everett Armstrong, whose arrival has done much to delay this publication.

FLOWERING PERIOD: Summer.

HABITAT: Widespread in lower subalpine areas in grassland.

DistribuTION: Subalpine areas of N.S.W. and Victoria.

Can be distinguished from other alpine and subalpine species by the shape of the flowering heads, being hemispherical rather than spherical, thus the involucral bracts 
of the general involucre are easily visible below and these are oblong. The leaves are bright green with inconspicuous hairs while most other species are glaucous or grey with fine hairs.

This seems to hybridise with orange-flowered species, C. crocata and C. aurantia, when they grow close together. This species was referred to as sp. B in Jacobs \& Pickard (1981) and as sp. $\mathrm{H}$ in Thompson (1981).

Selected specimens: New South Wales: Southern Tablelands: Prussian Creek, Thompson 2028, 31 Jan 1974 (NSW, CANB); c. 5 km NNE of Rennix Gap, Thompson 2504, 26 Jan 1976 (NSW); Upper Tumut R near Kiandra, Rodway 4489, Mar 1924 (NSW); Blackfellows Gap, c. 4 miles [6 km] N of Mt Bimberi, Schodde 1294, 15 Feb 1961 (CANB).

\section{C. aurantia Everett \& Thompson, sp. nov.}

Species capitulis compositis sphaericis aurantiis, foliis spathulatis, a speciebus nobis notis distincta.

Type: New South Wales: Southern Tablelands: Above Blue Lake, Kosciusko National Park, J. Thompson 2534, 27 Jan 1976 (holo NSW; iso CBG).

Robust herb with a single flowering scape $15-60 \mathrm{~cm}$ high, from a simple rootstock; roots thick, tomentose. Leaves mainly basal, spathulate, more or less attenuate at the base, acute to broad-acuminate, 2-16 cm long, 2-25 mm wide, and sparsely covered with multi-septate hairs or glabrous. Upper leaves lanceolate, linear-acuminate, stemclasping, $0.5-12.5 \mathrm{~cm}$ long, $1-16 \mathrm{~mm}$ wide. Inflorescence a single globose to hemispherical terminal compound head. Scape straw to red-brown, variously hairy. Compound head 1.5-3.0 cm diam., with c. 40-90 partial heads. Partial heads with 5-10 florets; main bract of the partial involucre broadly triangular to ovate, with a variable stereome usually ovate and herbaceous with hairs at the base and on the margins, and with membranous margins or lobes. Corolla orange; achenes $0.5-1.5 \mathrm{~mm}$ long, with appressed silky hairs; pappus of 14-19 plumose bristles 2-5 $\mathrm{mm}$ long.

DERIVATION: From the New Latin aurantia meaning orange, referring to the orange colour of the flowerheads.

FLOWERING PERIOD: Flowers summer.

HaBrTAT: In grassland. Common at higher subalpine levels, occasionally in sheltered alpine places where it appears to hybridise with yellow-flowered species.

Distribution: Alpine and subalpine N.S.W. and Victoria.

Can be distinguished by its spherical, orange-coloured flower heads and the spathulate green leaves, which are glabrous or inconspicuously hairy. This species was referred to as sp. D in Jacobs \& Pickard (1981), and as sp. F in Costin et al. (1979) and Thompson (1981).

Selected specimens: New South Wales: Southern Tablelands: Blue Cow Creek, Kosciusko Nat. Park, Thompson 1399, 19 Jan 1972 (NSW); near Charlotte[s] Pass, Skottsberg s.n., 14 Mar 1949 (NSW 245466); below Paralyser/Perisher saddle, Thompson 3089, 8 Apr 1979 (NSW, CBG n.v.). VICTORIA: north face of Mt Cope, van Rees 294, 31 Dec 1981 (MEL, NSW); $2.7 \mathrm{~km} \mathrm{~S}$ of Mt Nelse, Forbes 776, Adair \& Gray, 13 Jan 1982 (MEL, NSW). 


\section{C. costiniana Everett $\mathcal{E}$ Thompson, sp. nov.}

Species foliis dense pilosis a speciebus nobis notis distincta.

Type: New South WALEs: Southern Tablelands: above Lake Albina, Kosciusko dist., 6800ft. [2040 m], L.A.S. Johnson E E.F. Constable, 20 Jan 1951 (holo NSW 29293; iso CBG, MEL).

Conspicuously hairy herb with a single flowering scape $10-50 \mathrm{~cm}$ high, with a simple rootstock; roots thick, tomentose. Leaves mainly basal, spathulate, usually broad at the base, obtuse, 2.5-12 cm long, 2-11 mm wide; surfaces and margins densely and evenly covered with multi-septate, glandular hairs and long fine hairs, leaf tips glabrous. Inflorescence globose. Scape cream to crimson with scattered, long fine hairs and multi-septate or glandular hairs. Compound head $1.5-3.5 \mathrm{~cm}$ in diameter with up to 100 partial heads. Partial heads with 7-12 florets; main bract of the partial involucre broadly triangular to ovate, with an ovate herbaceous stereome with silky hairs, the margins membranous, colourless or dark brown. Corolla golden-yellow; achenes $0.75-1.5 \mathrm{~mm}$ long, with appressed silky hairs; pappus of 14-18 plumose bristles $2.5-5.5 \mathrm{~mm}$ long.

DERIVATION: Named in honour of Alec B. Costin, who has a deep and continuing involvement in the study and management of alpine areas.

FLOWERING PERIOD: Summer.

HАBITAT: In drier sites in alpine or high subalpine grassland.

Distribution: Endemic to Kosciusko National Park.

This species was referred to as sp. F in Jacobs \& Pickard (1981), and as sp. D in Costin et al. (1979) and Thompson (1981).

Selected SPecimens: New South Wales: Southern Tablelands: below Seamans Hut, Thompson 1419, 22 Jan 1972 (NSW); Mount Kosciusko, Curran s.n., Jan 1896 (NSW 245161); Soil Conservation Hut, N of Mt Carruthers, Totterdell 308, 17 Mar 1972 (CANB, NSW); Ramshead Range beyond Merritts Creek, E of Merritts Spur, Thompson 1707, 24 Jan 1973 (NSW, CANB); S of Mt Stilwell, Thompson 3043, 2 Apr 1979 (NSW, CANB).

\section{C. lamicola Everett \& Thompson sp. nov.}

Species foliis grandis turgidis, marginibus foliorum lanatibus, a speciebus nobis notis distincta.

TyPe: New South WALES: Southern Tablelands: below Seamans Hut, Kosciusko National Park, alt. $2000 \mathrm{~m}$, J. Thompson 1418, 22 Jan 1972 (NSW).

Stout flaccid-leaved herb with a single flowering scape $20-50 \mathrm{~cm}$ high; roots thick, tomentose. Leaves basal and cauline, gradually grading down in size up the scape, broadly spathulate, broadly stem-clasping, obtuse, 4-25 cm long, 1-4 cm wide; with a few multi-septate hairs and long fine hairs sparsely scattered over the surface, but usually fringing the margins densely; margins of upper leaves often undulate. Inflorescence a single globular compound head. Scape often tinged red, densely woolly especially just below the head. Compound head $1.5-3.5 \mathrm{~cm}$ in diameter with up to 90 partial heads. Partial heads with 7-11 florets; main bract of the partial involucre broadly triangular to ovate, with an ovate herbaceous stereome, glandular and with silky hairs, the margins membranous, and brown or colourless. Corolla golden-yellow; achenes 1-2.5 mm long, with appressed silky hairs; pappus of 15-22 plumose bristles 4-6 mm long. 
DERIVATroN: From the Latin lama, a bog or fen, and -cola, an inhabitant, referring to the boggy habitat.

FLOWERING PERIOD: Summer.

HАBITAT: In wet high alpine sites.

Distribution: Endemic to Kosciusko National Park.

This species was referred to as sp. E in Jacobs \& Pickard (1981) and as sp. E in Costin et al. (1979) and Thompson (1981).

Selected sPecimens: New SOuth Wales: Southern Tablelands: $S$ of Mt Stilwell, Thompson 3042, 2 Apr 1979 (NSW, CANB); Upper Snowy R. below road bridge, Thompson 1424, 22 Jan 1972 (NSW).

\section{Acknowledgements}

We wish to thank Andrew Doust for his technical assistance in the revision of Craspedia s.s. Australia-wide. Thanks are also due to Karen Wilson for help with the Latin diagnoses, and to Lani Retter, Leonie Stanberg, Ross Rowe and Dianne Godden for their assistance with the gathering of data. We are grateful to the heads of $A D$, PERTH, BRI, DNA, DNA, MEL, CANB, HO, CHR and AK for loans of specimens which have made this study possible. The work has been in part supported by grants from the Australian Biological Resources Study, which we gratefully acknowledge.

\section{References}

Costin, A.B., Gray, M., Totterdell, C.J. \& Wimbush, D.J. (1979) Kosciusko Alpine Flora (CSIRO/ Collins: Australia).

Jacobs, S.W.L. \& Pickard, J. (1981) Plants of New South Wales (Govt Printer: Sydney).

Thompson, J. (1981) A key to the plants of the subalpine and alpine zones of the Kosciusko region. Telopea 2(3): 219-297. 